SITES: NEW SERIES $\cdot$ VOL 15 NO $2 \cdot 2018$

DoI: http://dx.doi.org/10.11157/sites-id413

- ARTICLE -

SENIOR STUDENT ESSAY COMPETITION: 2018 AWARD WINNER

\title{
TĀ MOKO AND THE CULTURAL POLITICS OF APPROPRIATION
}

In what ways does Jean-Paul Gaultier's use of the Māori moko facial tattoo in a 2007 fashion campaign appropriate Māori culture, and how does this impact the agency and empowerment of Māori in upholding the mana of their own culture?

\author{
Mika Young $^{1}$
}

\begin{abstract}
With the rapid development of globalisation, issues of cultural appropriation - a topic of longstanding interest in social anthropology - have shifted and intensified in many ways. In recent decades the phenomenon has presented both challenges and opportunities for indigenous cultures across the globe to re-negotiate their cultural agency and empowerment. Grounded in the realm of cultural politics, I explore this issue through the iconic example provided by Jean-Paul Gaultier's 2007 'Vogue Magazine' campaign, in which European models were employed to display Aotearoa/New Zealand Māori tā moko while advertising clothing and sunglasses. There are several different solutions favoured by some Māori folk regarding this issue, all of which are underpinned by both opportunities and pitfalls. While I argue that solutions to issues of cultural appropriation should ultimately be led by the cultural groups who are directly affected, there is also room, I suggest, for anthropologists to play a role in this process. I envisage this to be through amplifying Indigenous voices, and by contributing to an enhanced awareness of the complexity of cultural appropriation.
\end{abstract}

Keywords: cultural appropriation; tā moko; cultural agency; globalisation; cultural politics.

\section{INTRODUCTION}

Tā moko are Māori designs or patterns which are tattooed onto the face and are deeply embedded in cultural significance and history. Moreover, tā moko 
are one of the most 'globalised of Māori taonga [treasures] today, aside from the All Blacks silver fern and Air NZ koru' (Tan 2013, 62). In recent years, there have been several different cases of the use of tā moko by non-Māori, from celebrities such as American boxer Mike Tyson or British singer Robbie Williams who had moko-inspired tattoos permanently inked into their faces, or Warner Brothers production company facing copyright lawsuits for mimicking Tyson's tattoo in a Hollywood blockbuster film. Another prominent case of the use of tā moko by non-Māori is Jean-Paul Gaultier's 2007 fashion campaign, in which tā moko were displayed on the faces of European models to advertise clothing and sunglasses in the European edition of 'Vogue' magazine. This essay seeks to analyse Gaultier's campaign in order to gain a comprehensive understanding of how this appropriates Māori culture, thereby impacting the agency and empowerment of Māori in upholding their own mana. ${ }^{2}$ This case is grounded in the realm of cultural politics, which Jackson defines as the domain in which meanings are constructed and negotiated, where relations of dominance and subordination are defined and contested' (Jackson in Bidois 2013). Gaultier's use of tā moko is therefore inseparable from the politicisation of Māori culture, through which the use of tā moko for Gaultier's personal gain is underpinned by an asymmetrical relationship of power and cultural appropriation between him and the Māori community.

In order to evaluate the cultural appropriation of tā moko by Gaultier in 2007, we must first understand cultural appropriation itself, and how it has been constructed across time. Cultural appropriation can be understood through multiple interpretations, although classical definitions tend to be particularly broad and have recently been problematised within the discipline of anthropology for being too simplistic. In analysing early colonial activities in North America, Biron defines cultural appropriation as 'the adoption of specific elements of one culture by a different cultural group' $(2016,20)$. This is a largely ambiguous definition which simply implies the transferral of ideas, activities or objects from one culture to another, and fails to sufficiently address issues of power and intent. It is argued that the notion of using 'appropriation' to define these acts can itself be understood as articulating the unequal power dynamic, as 'appropriation' is derived from the Latin root 'appropriare', meaning 'to make one's own' (Ashley and Plesch 2002, 3). This translation implies that an act of cultural appropriation inherently involves one exerting power over an 'other', through the act of taking something and using it for one's own purposes. Nonetheless, this understanding is problematic as it assumes that cultural groups are bounded, distinct entities, between which elements can be exchanged arbitrarily. This understanding of culture is now widely criticised, as the assumption of distinct boundaries between static cultural groups is 
founded on ideas of cultural essentialism, because it ignores the long history of cross-cultural interaction and influence which has taken place across the world (Schneider 2003, 217). From this, it is clear that there are several important elements of cultural appropriation to be considered, and attention must be given to the interconnectedness between cultural groups to avoid notions of cultural essentialism. Furthermore, cultural appropriation cannot be understood through analysis of culture alone. The power imbalance between the appropriator and appropriated and the motivations to take elements of one culture for another's gain are critical in understanding and assessing acts of cultural appropriation, thus revealing the complex and interwoven relationship between culture and power.

In recent decades, classical interpretations of cultural appropriation have been increasingly critiqued in ethnographic literature. While anthropologists agree that power disparities are at the core of cultural appropriation, the assumption that the appropriator has unequivocal power over the appropriated is now challenged, particularly as technological advances and global interconnectedness, fuelled by globalisation, create new ways for those with less power to exert their own agency over one-another and towards those at the centre. Recent studies analyse the two-way flows between the dominant group and the minority, highlighting the ability of the minority to engage with acts of cultural appropriation, despite their limited power (Ashley and Plesch 2002, 6). One example of this can be seen in the practice of 'bricolage', a concept developed by Levi-Strauss to describe the practice of minority cultural groups taking elements of the dominant culture, which are then 'tinkered' with, subverting and re-creating meaning to conduct a diverse range of tasks (Luvaas 2010, 5). Luvaas studies the practice of bricolage in Indonesian fashion, in which Indonesian artists manipulate well-known fashion motifs and imagery which flow in from countries such as the United States of America. Through creating their own meaning, these artists develop their own brands. This practice enables mostly young Indonesian urbanites to gain some agency in the continuous growth of transnational, Western capitalism in Indonesian society (Luvaas $2010,2)$. It must be noted, however, that while this enables Indonesian folk to access the capitalist economy, the financial revenue they generate is far lower than that of the multi-national companies whose imagery is subverted, and so this position of power remains limited. Thus, while classical interpretations of cultural appropriation can be challenged through practices particularly enabled by globalisation, the agency of the minority in engaging with these practices remains limited. The nuances of power and agency are also present within the appropriation of tā moko, which I now move to untangle. 
In order to explore the impact of cultural appropriation of tā moko, we must first seek to understand the cultural context and transformation of tā moko within Māori society. It is beyond the scope of this essay to give a comprehensive account of the origins and history of tā moko, however, there are some key ideas to be understood. Pearless explains that the practice came about for Māori through the inspiration of Rūaumoko, the god of earthquakes. He explains that 'rü' refers to the state of the Earth prior to earthquakes and eruption, 'au' is the alluvial table that lies beneath the skin of Papatuanuku (Mother Earth), 'moko' refers to the issuing forth of lava, and so, 'our people, when they saw that, and they saw the scarification of the land as black as it was, what they did was they took that mark and they chiseled it into their faces' (Webby 2007, 00:56-01:05). It must also be noted that there are various forms of tā moko with different purposes and meanings, and these continue to change over time. In reference to how tā moko was practiced and understood by Màori ancestors, tā moko artist Mark Kopua states; 'Normally the patterns tell of progression in their status, it tells whether they've inherited the mana, or whether they've earned it, tells people of what they've done in their lifetime' (Museum of New Zealand Te Papa Tongarewa 2011, 0:48-1:05). This does not prevent tā moko from adapting to the changing conditions in which Māori culture develops over time. For example, Te Awekotuku highlights the empowerment of wāhine (women) Māori which can come from the wearing of moko kauae, ${ }^{3}$ for all women [spoken to in her project], the kuia were a close, and usually vivid, living, memory. They chose designs, and their placement, in ways that remembered their kuia, or declared their femininity and value as wāhine Māori' (Te Awekotuku 2007, 89). However, for Ngatai Melbourne, another wahine Māori, the decision to get a moko kauae was inspired by a particular myth; 'Something that my father taught me when he was alive was something that he learned from one of his tipuna (grandparents or ancestors), and that was that to receive a moko kauae, it normally meant there had been... that something terrible had happened, so his death to me was something terrible' (Webby 2007, 02:37-02:53). Thus, it is clear that tā moko have deep cultural significance, which is influenced by history and yet can change over time. As Te Awekotuku poignantly explains; 'Moko is about the future, just as it is about the past; it is a graphic accounting of memory and desire; it is an engraving, on the Māori body, of history and commitment, of loyalty and relationships' (Te Awekotuku 2007, 008).

Significantly, tā moko have not existed in isolation from cross-cultural influences and understandings only to be influenced by recent waves of globalisation and commodification, as colonial forces had a long and influential role in 
their contemporary context and practice. In order to appropriate something, one first needs to create an understanding of it, and early British colonists constructed their own understandings of Māori culture and practices through engaging in what is now recognised as a form of Orientalism. A concept coined by Said, Orientalism describes 'a Western style for dominating, restructuring and having authority over the Orient', where the Orient came to denote the juxtaposed 'other' of 'the West' (Burney 2012, 23). As a means of constructing the other, cultural knowledge was created largely within the imaginations and localities of Western nations themselves, and often shared little resemblance to the lived reality in the places that cultural knowledge was created about. This was no different in colonial interpretations of tā moko. Interpreting tā moko in nineteenth century Western thought, the practice was constructed to contrast notions of modern Western civilisation, and therefore were perceived as 'a sign of savage or barbaric social behaviour exhibited by "primitive" societies' (Pritchard 2001, 28). As colonial understandings of tā moko were constructed through the Western gaze, this led to subjectification and objectification of the practice in environments such as World Fairs, which were some of the earliest forms of Western appropriation of tā moko, creating inaccurate and essentialised understandings of tā moko, far removed from the context in which they were practiced. Moreover, the desire of early missionaries to 'civilise' Māori society drove their aggressive efforts to 'stamp out' tā moko altogether (Te Awekotuku 2007, 85). Despite the intent to eradicate the practice, Māori mokomokai ${ }^{4}$ have also been displayed in European museum collections since at least the early nineteenth century, thus proliferating the exoticisation and objectification of Māori culture in Europe (Tan 2013, 64). Therefore, the harmful interpretations, subjectification, and aggressive attempts at eradication of Māori culture by colonists continues to have a strong and relevant influence on how Māori engage with non-Māori use of tā moko today.

As previously discussed, recent analyses of cultural appropriation are careful not to over-emphasise the asymmetrical power relations between the appropriator and the appropriated. Therefore, while acknowledging the exertion of power and manipulation of Māori culture by colonists in New Zealand, we must also pay attention to the actions and agency exerted by Māori themselves in reaction to colonial influences on tā moko. As Panoho notes, 'there is a whole underexposed history of innovative and aggressive Māori adoptions of Pākehā forms, design, technologies and materials, particularly from the nineteenth century' (Panoho in Pritchard 2001,35). One example of this is the introduction of British tattooing technology which became incorporated into the practice of applying tā moko. Prior to colonial contact, tã moko were carved into the skin solely through the use of uhi, chisels made out of bone, which cut the top layers 
of the skin in order to insert the ink. However, the introduction of the metal tattoo gun created a much darker and clearer design, and also generated much less bleeding, therefore transforming the aesthetics and practice of tā moko. Māori also gave some Pākehā their own moko, for instance as a result of intermarriage or as a sign of their involvement with a particular hapu or iwi (Webby 2007, 01:12-01: 28). This giving of tā moko to Pākehā denotes an incorporation of some Pākehā into Māori society just as Māori were being incorporated into Pākehā society. Thus, the interaction between Māori and Pākehā is complex, and cultural flows have existed both ways across time. However, it is important to note that while Māori have had limited abilities to exert their own cultural power through their relations with Pākehā, the subjectification and objectification of Māori culture throughout colonisation has created a harmful legacy which continues into issues of appropriation today.

Before moving on to discuss the cultural appropriation of tā moko by Gaultier, it is important to note that in my identity as a Pākehā, researching and discussing a Māori practice is underpinned by complex ethical considerations relating to my own identity and place in New Zealand. Although I do not have Māori ancestry or connections with any hapu or iwi, my identification as a Pākehā rather than simply as European highlights the complexity of this specific settler identity. As Black notes, the identification with Pākehā symbolises the recognition of Māori as tangata whenua (people of the land or indigenous people), as a treaty partner to which one has responsibilities to uphold, and also signifies a cultural identity as both of Northern European origin yet also denoting a unique sense of belonging to Aotearoa (Black in Forsyth 2018, 73). ${ }^{5}$ Therefore, in discussing this subject I intend to remain aware of this unique position and hence the limitations in my contribution to the issue, yet also the opportunity to amplify Māori voices and contribute to enhancing awareness of Western cultural appropriation of Māori practices such as tā moko. With this in mind, I now turn to look at the appropriation of tā moko through the fashion campaign by Gaultier in 2007.

\section{THE JEAN-PAUL GAULTIER CAMPAIGN}

In 2007, European editions of the magazine 'Vogue' displayed images of men and women with tā moko on their faces in order to advertise clothing and sunglasses (figure 1). Gaultier had no contact with Māori iwi before deciding to use the moko in his campaign, and there is no further information given alongside the images regarding how the moko were selected, applied to the faces of the models, or the significance or meaning behind them. It is interesting to note, however, that Gaultier appears to have captured the mana which 


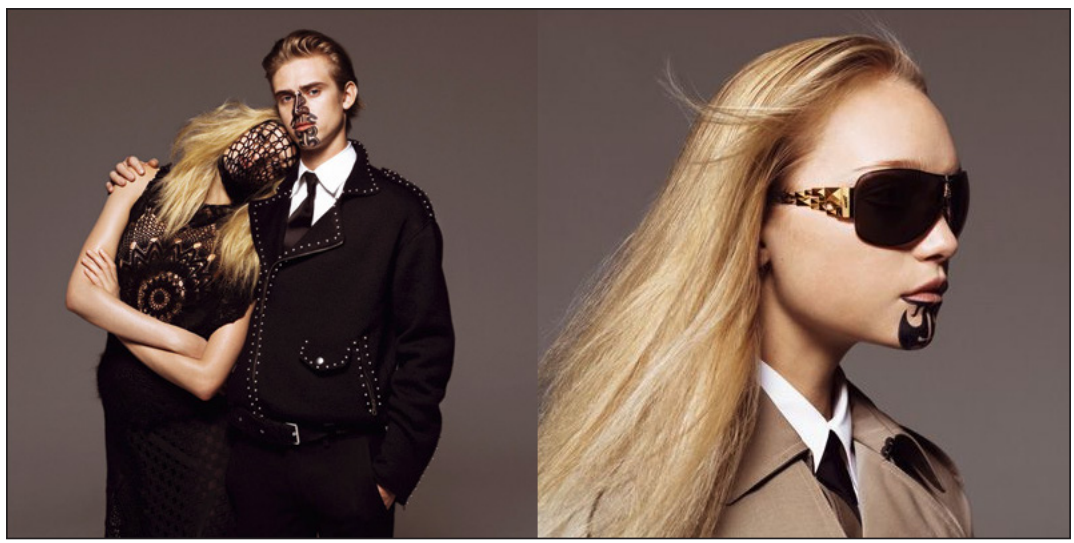

Figure 1. Images used by Gaultier in his 2007 campaign

is associated with the moko in order to create a sense of power in the images. The campaign was received in a variety of perspectives in New Zealand, and several news outlets have since picked up on the campaign. Stuff, the online news outlet, produced an article in which it noted; 'Fashion blogs [as a result of the magazine] have picked a cannibal theme, with one headed: "I'll eat your liver and still look fabulous"', and, within the same article, described one photo which had 'a female model with a moko and posed sitting with her legs open' (Fairfax Media 2009a). Although these fashion blogs were only a result of the campaign, this is nonetheless highly problematic, as it uses the campaign to draw back to colonial fantasies of exoticism and the notion of the 'primitive', thereby dehumanising and othering Māori in order to develop readership through sensationalised imagery and wording.

Despite this, perspectives of New Zealand folk regarding Gaultier's campaign are varied. In a reader's response section to the aforementioned Stuff article, Marsh L raises concerns about the respect of Māori values in stating:

The message may be that Maori culture is 'exotic and beautiful', but the way it's being portrayed in their images and on their models conflicts with basic Maori tikanga ${ }^{6}$ and values surrounding women and ta moko itself. I would be more at ease with this if some greater background homework had been done on their part. Even if this were to be as basic as asking a few questions, or even better if they culd [sic] have consulted someone. In doing so they could have avoided takahi ${ }^{7}$ on the mana of tā moko and Maori tikanga. (Fairfax Media 20ogb) 
This comment reflects the concern with taking tā moko out of its cultural context, that the use of tā moko out of context negatively affects Māori mana, and suggests that dialogue or permission could resolve the problem. However, others were more positive about the images, such as Kerry Hand, who contrasts the previous opinion in noting; 'I think it's just great what Gaultier has done. Looks really good and an advance on the current stuff. It's time people stopped trying to set these designs in concrete. Grow change and develop I say' (Fairfax Media 2009b). Hawkins, a Māori tikanga and Te Reo Māori teacher effectively highlights the problematic power imbalance which underpins Gaultier's cultural appropriation of tā moko in stating; '[The campaign] had me wondering why a creative genius, with an estimated net worth of $\$ 100$ million, needed to exploit a Māori art form to help build his already impressive fashion empire' (Hawkins 2018). These comments reflect that although there are various perspectives of the campaign, the underpinnings of power and culture cannot be isolated or ignored in Gaultier's decision to use the moko in his images. Through Gaultier's complete disregard to engage in dialogue with Māori in if and how it is appropriate to incorporate tā moko in his images, Māori are left with very little control over how their culture and their taonga are seen and engaged with in a globalised world.

The campaign engages in a prominent debate which has long been present in colonial and post-colonial discourse, namely whether the use of indigenous and non-Western cultural artefacts by powerful states and groups in society is an act of appreciation or an act of harm. For example, in discussing the use of Indian clothing by non-Indian folk in the United States of America, Patel argues that the ability to 'select' elements of other cultures for one's own consumption is problematic, particularly insofar as this ignores the oppression and marginalisation which people from states such as India have experienced and continue to experience today (Patel 2016). In analysing a Coldplay music video in which the singer Beyoncé wore an Indian sari despite not being of Indian descent, Patel writes:

Growing up I was regularly teased and bullied for wearing traditional Indian clothing. To see Beyoncé, Gwen Stefani, or any number of random white women on the street wearing those same outfits or accessories as a novelty is a slap in the face. You see; they can choose to take off the costume, and return to their daily lives when they want. I am unable to not inhabit the inherent Indianness of my appearance. No one wants to engage with the parts of a culture that aren't cute outfit options. (Patel 2016) 
This same issue is faced, albeit in a different way, by Māori today, as the visibility of tā moko subjects Māori folk to oppression and marginalisation in New Zealand society. For instance, a recent tweet gained traction on social media which read; 'A Māori girl got suspended from my sister's highschool [sic] for getting her Tā moko. Pākehā should be more aware that Māori are still punished for practicing their own culture' (Alex 2018). Māori also continue to face oppression in public spaces for their moko, as Pearless has experienced: 'The only place that I've had issues with moko in the world are here in New Zealand, Aotearoa. I've been stopped by the police a couple of times and um, I have no issues with the police, but I just ask why, why have I been stopped, and you get an array of answers' (Webby 2007, 01:30-01:50). It could thus be argued that promoting Māori culture on a global scale can be understood as positive in that it is 'cultural appreciation' or visibility. However, it is not only the lack of Māori consultation or cultural context in Gaultier's use of the moko which is deeply harmful to Mãori agency and mana, but also the societal oppression which Māori continue to face today through the visibility and practice of tā moko in New Zealand.

\section{SOLUTIONS TO CULTURAL APPROPRIATION OF TA MOKO}

Thus far I have explored the complexities of cultural appropriation and the problematic nature of cases such as Gaultier's fashion campaign in the use of tā moko for commercial gain. This is not a standalone issue, as exhibited by international celebrities such as Mike Tyson choosing to receive permanent tā moko. This particular case caused a controversy when Tyson's tattoo artist Scott Whitmill, also an American, attempted to copyright the design to prevent Warner Brothers Studios from replicating it on a character in their film 'The Hangover II', despite the moko design clearly being Māori (Tan 2013, 64). This has led some Māori and Pākehā to explore the possibility of enacting international legislation as one solution to give Māori ownership over their cultural taonga. However, developing legislation within international legal systems forces an individualistic notion of ownership and cultural property over taonga which are understood through communal notions of ownership and cultural property within Māori communities. Tā moko, while having variations in meaning between some Māori folk and others, tend to be understood as a continuation of ancestral tradition and located in ancestral meaning. Thus, the ownership of tā moko can be described as 'collective indexes of agency', in which Delanda's assemblage theory can be usefully applied (Tan 2013, 67). Assemblage theory denotes the concept of 'the individual' not as a singular person but as a singular entity, connected with other assemblages and therefore capable of transformation (Tan 2013, 64). Through this framework, tā moko can 
be understood as owned by a collection of assemblages, connected by 'blood, flesh, ink and memory' (Tan 2013, 67). This contrasts Western legal understandings of ownership, in which a particular person or defined group of people are understood as the 'owner', and a multi-generational and fluid conception of ownership is not recognised. This is not to say that legislation may not be the most desirable solution from the perspective of some Māori folk, but that the politicisation and legalisation of Mãori culture presents both opportunities in giving some protection and control to Māori, but also consequences such as the contrasting understandings of ownership and cultural property.

Gaultier's appropriation of tā moko is just one case of contemporary cultural appropriation which has problematic effects on the cultural groups being appropriated. However, in the post-colonial and globalised environment in which new challenges to cultural revival and survival are faced by many indigenous communities, it is perhaps most effective to negotiate relationships of cultural appropriation and commodification through dialogue and negotiation. For example, the revitalisation of some Aboriginal cultures in Australia which has led to increasing commodification of cultural practices such as traditional healing has enabled Heather, an Aboriginal woman who was distanced from her heritage and experienced familial separation as a child, to re-connect to her Aboriginal culture through developing her own form of an Aboriginal healing ceremony, which she sells to both Aboriginal and white Australians (Muir 2007, 243). Heather's practice can be understood as a creative way to reconstruct and create new meanings for elements of Aboriginal culture in order for Heather to form a connection to her cultural heritage, and enhance both her own wellbeing and that of her customers. A similar practice is analysed in Cowlishaw's account of Aboriginal cultural revivalism, in which she looks at the practice of teaching Aboriginal school children to make their own totems out of toilet rolls, although the practice is carried out in a simplified and arguably decontextualised way in the classroom (Cowlishaw 2012). However, Cowlishaw comes to the conclusion that while the practice seems far removed from that of Aboriginal ancestors, it can be perceived as one solution to the problems faced by some Aboriginal communities in carrying on and teaching cultural practices to their children in an accessible way (Cowlishaw 2012, 404).

These instances of adaptation to postmodern conditions in which culture is constantly negotiated and re-constructed also provide possible solutions to the problems faced by Māori in the commodification and appropriation of tā moko today. Rather than rejecting involvement in the increasing use of tà moko by non-Māori, some Māori seek to involve themselves with these practices in order to have some agency over how they are carried out. This draws 
some similarities with Horowitz's study of indigenous women's oppression in New Caledonian mining, in which women sought to counter this by involving themselves directly in mining, and starting their own committees and groups to have some influence in decisions made which affect their cultural identities and practices (Horowitz 2017). One example of this is the practice of teaching the cultural meanings of tā moko to non-Māori tattoo artists. Stu McDonald, a Māori tā moko artist, does exactly this. He has spent many years of his professional life travelling the world and teaching non-Māori tattoo artists how to approach and apply tā moko in a way which is congruent with Māori practices and beliefs. McDonald recognises the complexity of appropriation in the contemporary world, stating; 'The issues that have come with globalisation and commercialisation with the taonga are huge, you know, and it would actually be hard to undo that stuff', and so he feels that teaching tattoo artists some cultural context is one way to combat this (Murray 2018). Another way which some Māori seek to navigate postmodern conditions is through the use of language, which Brimacombe posits can be a form of glocalisation, melding together languages and therefore meanings between the appropriator and the appropriated (Brimacombe 2016). This is demonstrated through the introduction of 'kirituhi', a word which translates simply to 'skin art', used to simulate the Western understanding of 'tattoo' and denote the practice of non-Māori getting tattoos inspired by tā moko. While this enables Māori to distinguish between culturally significant and meaningful practices of tā moko and the giving of moko-inspired tattoos without cultural significance to non-Māori, it is nonetheless controversial within Māori communities. Some rightfully argue that this distinction cannot prevent the exoticisation and exploitation which comes from the visual imagery of tā moko being used in non-Māori contexts, particularly in commercialisation, while others argue that it is a great marketing ploy', as it can resemble moko, yet be distinguished from it simply through the fact that it sits on non-Māori skin (Te Awekotuku 2007, 135).

\section{CONCLUSION}

Gaultier's fashion campaign in which Māori tā moko were used to sell clothing and sunglasses to a European market highlights the complexity and continued impact of cultural appropriation in contemporary society. The appropriation of tā moko must be understood through a historically-grounded framework, and it is consequently evident that Gaultier's use of tā moko ultimately had a negative impact on Māori mana and agency, as it was used without consultation, devoid of cultural context and, while it could be perceived by some as a celebration or promotion of Māori culture, it ignores the oppression and stigmatisation of Māori which has existed throughout colonisation and persists 
today in Aotearoa/New Zealand society. The inextricable connection between power and culture underpins Gaultier's campaign, and although we cannot separate one from the other, through an anthropological analysis we are able to explore their relationship and find meaningful ways forward, if not solutions.

Nevertheless, in order to prevent continued colonial forces of asymmetrical power and domination, we should ensure that these discussions and the decisions on how to move forward include, and are ultimately led by, the voices of those who these issues most pertinently affect, which in this instance means the inclusion and leadership of Māori folk themselves. As I have discussed, some solutions supported and proposed by Māori include consultation with non-Māori who engage with tā moko such as foreign tattoo artists or creating new linguistic categories such as kirituhi, and for cases of copyright, developing legislation. All of these cases are viewed through varying perspectives, shaped by both opportunities and consequences in creating more agency for Māori, yet remaining subject to non-Māori structures and interpretations. These are all possibilities which provide a basis for further research and exploration into meaningful ways to negotiate cultural appropriation of tā moko in contemporary society.

\section{ACKNOWLEDGEMENTS}

I would like to thank Ruth Fitzgerald, Susan Wardell and the other contributing lecturers for developing and teaching the wonderful new ANTH 312: Cultural Politics course at the University of Otago this year, for which this essay was written. I would also like to thank Kohu Douglas for his assistance in translating the Māori terminology used in this essay.

\section{NOTES}

1 Mika Young is in their final year of a BA in social anthropology at the University of Otago. Their research interests include cultural politics, medical anthropology and LGBTQ+ issues.

Email:mika.j.young@gmail.com

2 'Mana' has a complex meaning not easily translated into English, but can be roughly understood as 'prestige' or 'honour'.

3 Moko kauae are tattoos for wāhine positioned on the chin. 
4 Mokomokai are preserved heads covered in tā moko, usually after having been decapitated in warfare.

5 Aotearoa is the Māori name for New Zealand.

6 Tikanga has no succinct translation to English, however it can be roughly translated as 'the Māori way of doing things', including rules, beliefs, customs and practices.

7 Takahi roughly translates to 'to trample'.

\section{REFERENCES}

Alex (@alxjasper). 2018.'A Māori girl got suspended from my sister's highschool for getting her Tā moko. Pākehā should be aware that Māori are still punished for practicing their own culture'. Twitter post, 22 May 2018. Accessed 1 June 2018 from https://twitter.com/alxjasper/status/999133631439224835

Ashley, Kathleen, and Veronique Plesch. 2002. 'The Cultural Processes of "Appropriation"'. Journal of Medieval and Early Modern Studies 32 (1):1-15.

Bidois, Vaughan. 2013. 'A Genealogy of Cultural Politics, Identity and Resistance: Reframing the Māori-Pākehā Binary'. AlterNative: An International Journal of Indigenous Peoples 9 (2):142-154.

Biron, Gerry. 2016. 'The Cultural Appropriation of American Indian Images in Advertising 1880s-1920'. Whispering Wind 44(3):20-25.

Brimacombe, Tait. 2016. 'Trending Trousers: Debating Kastom, Clothing and Gender in the Vanuatu Mediascape. The Asia Pacific Journal of Anthropology 17 (1): 17-33.

Burney, Shehla. 2012. 'Chapter One: Orientalism: The Making of the Other'. Counterpoints 417:23-39.

Fairfax Media. 2009a. 'Cheeky French steal moko'. Accessed 1 June 2018 from http://www.stuff.co.nz/life-style/fashion/44467/Cheeky-French-steal-moko

Fairfax Media. 2009b. 'Your Say: Cheeky French steal moko'. Accessed 1 June 2018 from http://www.stuff.co.nz/blogs/opinion/your-say/40874/Your-Say-iCheeky-French-steal-moko-I 
Forsyth, Huhana. 2018.'An Identity as Pākehā'. AlterNative: An International Journal of Indigenous Peoples 14 (1):73-80.

Hawkins, Nicole. 2018. 'You can't copyright culture, but damn I wish you could', Accessed 1 June 2018 https://thespinoff.co.nz/atea/20-03-2018/you-cantcopyright-culture-but-damn-i-wish-you-could/

Horowitz, Leah. 2017. "It Shocks Me, The Place of Women”: Intersectionality and Mining Companies Retrogradation of Indigenous Women in New Caledonia'. Gender, Place and Culture 24 (10):1419-1440.

Luvaas, Brent. 2010. 'Designer Vandalism: Indonesian Indie Fashion and the Cultural Practice of Cut 'n' Paste. Visual Anthropology Review 26 (1):1-16.

Muir, Stewart. 2007. 'The Good of New Age Goods: Commodified Images of Aboriginality in New Age and Alternative Spiritualities. Culture and Religion $8(3): 233-253$.

Murray, Justine. 2018. 'Taa Moko Sessions: Stu McDonald'. Accessed 21 May 2018 from https://www.radionz.co.nz/national/programmes/teahikaa/audio/201864554o/taa-moko-sessions-stu-mcdonald

Museum of New Zealand Te Papa Tongarewa. 2011. 'Carved In Skin - Tales from Te Papa episode 84', [video], Accessed 24 May 2018 from https://www.youtube. com/watch?v=AdB96TMJu74\&feature=youtu.be

Patel, Zoya. 2016. 'How to appreciate a culture without appropriating it'. Accessed 21 May 2018 from https://i-d.vice.com/en_us/article/zmx5dx/how-to-appreciate-a-culture-without-appropriating-it

Pritchard, Stephen. 2001. 'An Essential Marking: Māori Tattooing and the Properties of Identity'. Theory, Culture and Society 18 (4):27-45.

Schneider, Arnd. 2003. 'On “Appropriation”. A Critical Reappraisal of the Concept and its Application in Global Art Practices'. Social Anthropology 11 (2):215-229.

Tan, Leon. 2013. 'Intellectual Property Law and the Globalisation of Indigenous Cultural Expressions: Māori Tattoo and the Whitmill versus Warner Bros. Case.' Theory, Culture and Society 30 (3): 61-81.

Te Awekotuku, Ngahuia, Linda Waimarie Nikora, Mohi R. Rua, Rolinda Karapu, 
SITES: New Series · Vol 15 No $2 \cdot 2018$

and Becky Nunes. 2007. Mau Moko: The World of Māori Tattoo. North Shore, New Zealand: Penguin Viking.

Webby, Kim. 2007. 'Tā Moko [online excerpt one]'. Accessed 21 May 2018 from https://www.nzonscreen.com/title/ta-moko-2007 